\title{
RANGE EXPANSION OF THE VULNERABLE CRAYFISH CREASERINUS FODIENS (COTTLE, 1863) (DECAPODA, CAMBARIDAE) IN ONTARIO, CANADA, WITH ADDED NOTES ON THE DISTRIBUTION, ECOLOGY AND CONSERVATION STATUS OF THIS SPECIES IN NORTH AMERICA
}

\author{
BY \\ RADU C. GUIAŞU ${ }^{1}$ ) \\ Biology Program, Glendon College, York University, 2275 Bayview Avenue, Toronto, \\ Ontario, M4N 3M6, Canada
}

\begin{abstract}
The distribution of the semi-terrestrial burrowing crayfish Creaserinus fodiens (Cottle, 1863) in Ontario was updated based on the examination of the records stored in the crayfish database of the Royal Ontario Museum in Toronto and specimens collected during field studies. New Ontario locality records are reported for this crayfish species from MacGregor Point Provincial Park and other nearby sites in Bruce County, along the shores of Lake Huron. These are among the northernmost locality records reported for this species in North America. These new records represent a northwestern range expansion for this crayfish species in southern Ontario. As a result of these new records, the revised distribution of this species in Ontario is estimated to cover an area of about $32620 \mathrm{~km}^{2}$. This is an increase of $7620 \mathrm{~km}^{2}$ over a previous 1996 estimate of this range. Creaserinus fodiens is a vulnerable species in Ontario, mainly due to the loss of suitable wetland habitats. Thus, the new locations and the range expansion reported here provide some hopeful news about the long-term future of burrowing crayfishes in this Canadian province. At some of the new locations, $C$. fodiens was found together with Faxonius immunis (Hagen, 1870), another burrowing crayfish species. However, this analysis of all the relevant records found in the collections of the Royal Ontario Museum (Toronto) and the Canadian Museum of Nature (Ottawa) shows that our knowledge of the distribution of $C$. fodiens in Ontario remains quite incomplete. A survey of the conservation status and challenges for this crayfish species in various regions of North America was also undertaken.
\end{abstract}

\section{RÉSUMÉ}

La répartition de l'écrevisse fouisseuse semi-terrestre Creaserinus fodiens (Cottle, 1863) en Ontario a été actualisée à partir de l'examen des documents stockés dans la base de données sur les écrevisses du Musée royal de l'Ontario à Toronto et des spécimens collectés au cours d'études de terrain. De nouvelles données de localités en Ontario sont rapportées pour cette espèce d'écrevisse

\footnotetext{
1) e-mail: rguiasu@glendon.yorku.ca 
du parc provincial MacGregor Point et d'autres sites voisins dans le comté de Bruce, le long des rives du lac Huron. Celles-ci comptent parmi les localités les plus septentrionales mentionnées pour cette espèce en Amérique du Nord. Ces nouvelles mentions représentent une expansion vers le nord-ouest pour cette espèce d'écrevisse dans le sud de l'Ontario. Comme résultat de ces nouveaux signalements, la répartition révisée de cette espèce en Ontario est estimée comme couvrant une région d'environ $32620 \mathrm{~km}^{2}$. Ceci représente une augmentation de $7620 \mathrm{~km}^{2}$ par rapport à la précédente estimation de 1996. Creaserinus fodiens est une espèce vulnérable en Ontario, principalement en raison de la perte d'habitats humides appropriés. Ainsi, les nouveaux sites et l'expansion de la répartition rapportés ici fournissent des informations prometteuses sur le futur à long terme des écrevisses fouisseuses dans cette province canadienne. Dans certains de ces nouveaux sites, $C$. fodiens a été trouvée avec Faxonius immunis (Hagen, 1870), une autre écrevisse fouisseuse. Cependant, cette analyse de tous les documents pertinents trouvés dans les collections du Musée royal de l'Ontario (Toronto) et du Musée canadien de la nature (Ottawa) montre que notre connaissance sur la répartition de $C$. fodiens en Ontario demeure très incomplète. Un suivi du statut de conservation et des risques pour cette espèce d'écrevisse dans diverses régions d'Amérique du Nord est aussi engagé.

\section{INTRODUCTION}

Creaserinus fodiens (Cottle, 1863), known until 2017 as Fallicambarus fodiens (Cottle, 1863), is a widely distributed semi-terrestrial primary burrowing crayfish species native to eastern and central North America (Crocker \& Barr, 1968; Guiaşu, 2007). The range of this species stretches from southern Ontario in the north to Texas, Louisiana and Florida in the south (Guiaşu, 2007; Taylor et al., 2007; Crandall, 2010). Despite its large range, C. fodiens, which is also known as the digger crayfish, is considered vulnerable in some regions due mainly to habitat destruction and pollution (Guiaşu, 2007). In Ontario, the only Canadian province where $C$. fodiens is found, this burrowing crayfish species is vulnerable and found at relatively few wetland and drainage ditch locations scattered across the southern part of the province. Burrowing crayfish, including C. fodiens, require suitable clay soils in order to dig their tunnels, and in most of Ontario, north of Lake Simcoe, the substrate consists of the hard rocks of the Precambrian Shield, which should prevent substantial northern expansions of the range of such crayfish (Guiaşu et al., 1996a; Guiaşu, 2002a).

However, the distributions of crayfish species in Ontario are generally poorly known, and additional field work is required in order to fill the major gaps in our knowledge of the ranges and ecology of these species (Guiaşu, 2016; Pereyra \& Guiaşu, 2020). In this study, I report a significant northward range expansion of $C$. fodiens in Ontario, update the estimated total area occupied by this species in this Canadian province, and comment on the distribution, ecology and conservation status of this burrowing crayfish in various regions of North America. 


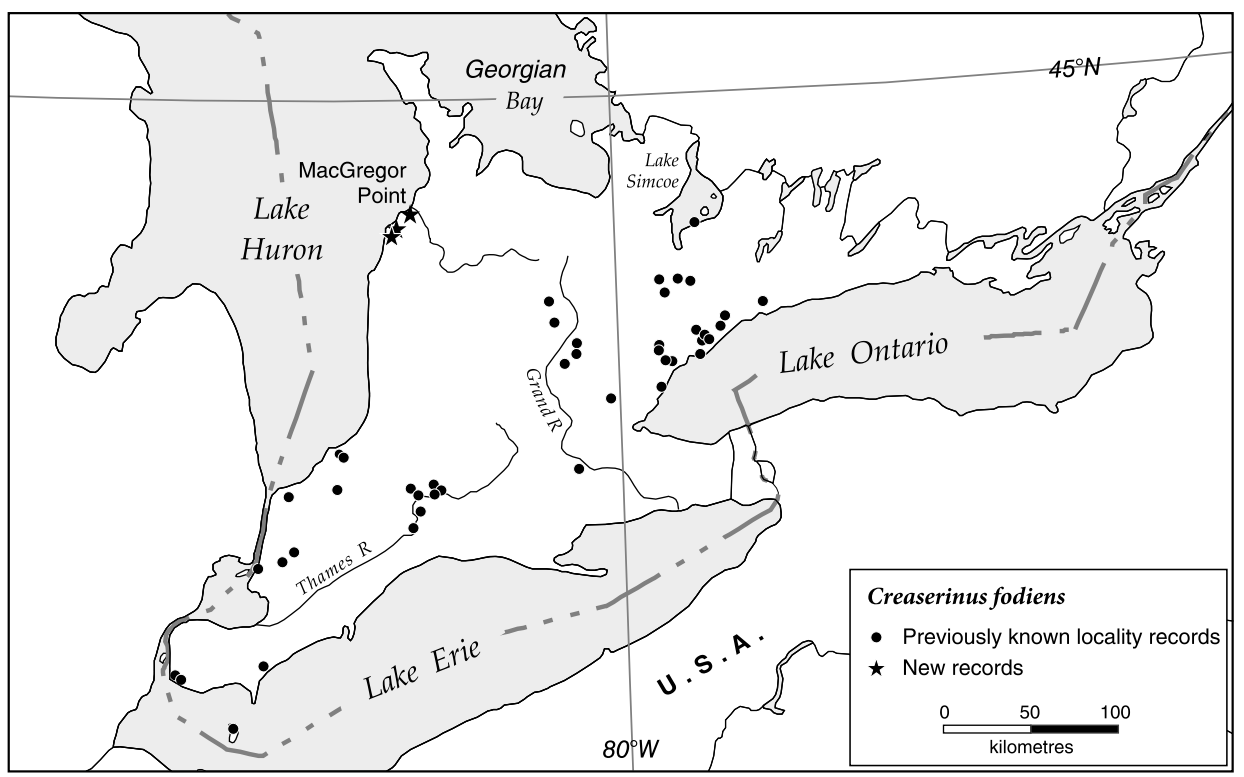

Fig. 1. The distribution of Creaserinus fodiens (Cottle, 1863) in Ontario, showing the new locations at and near MacGregor Point on the shores of Lake Huron.

\section{RANGE EXPANSION FOR CREASERINUS FODIENS IN ONTARIO}

New Ontario locality records are reported for Creaserinus fodiens from MacGregor Point Provincial Park $\left(44^{\circ} 25^{\prime} \mathrm{N} 81^{\circ} 27^{\prime} \mathrm{W}\right.$ and $\left.44^{\circ} 24^{\prime} \mathrm{N} 81^{\circ} 27^{\prime} \mathrm{W}\right)$ and other nearby sites, such as Baie du Doré $\left(44^{\circ} 20^{\prime} \mathrm{N} 81^{\circ} 33^{\prime} \mathrm{W}\right)$ and a railway ditch $\left(44^{\circ} 19^{\prime} \mathrm{N} 81^{\circ} 34^{\prime} \mathrm{W}\right)$ in Bruce County, along the shores of Lake Huron (fig. 1). These are among the northernmost locality records reported for this species in North America. C. fodiens have never been collected before this far north along the shores of Lake Huron, to the southwest of the Bruce Peninsula. These new records represent a significant northwestern range expansion for this crayfish in southern Ontario. The distances between the closest previously reported locations for this species (shown in Guiaşu et al., 1996a) and these new locations are: $146.83 \mathrm{~km}$ (distance A, which is a northern range expansion along the shore of Lake Huron), $95.69 \mathrm{~km}$ (distance $\mathrm{B}$, which is a northwestern range expansion from near the northwestern side of the Grand River), and $164.63 \mathrm{~km}$ (distance C, which is an almost straight line western range expansion from the southern shore of Lake Simcoe), respectively (fig. 2). As a result of these new records, the revised and extended distribution of this species in Ontario is estimated to cover an area of about $32620 \mathrm{~km}^{2}$ (fig. 3). This is an increase of $7620 \mathrm{~km}^{2}$ over a previous estimate of this range $\left(25000 \mathrm{~km}^{2}\right)$ reported by Guiaşu et al. (1996a). 


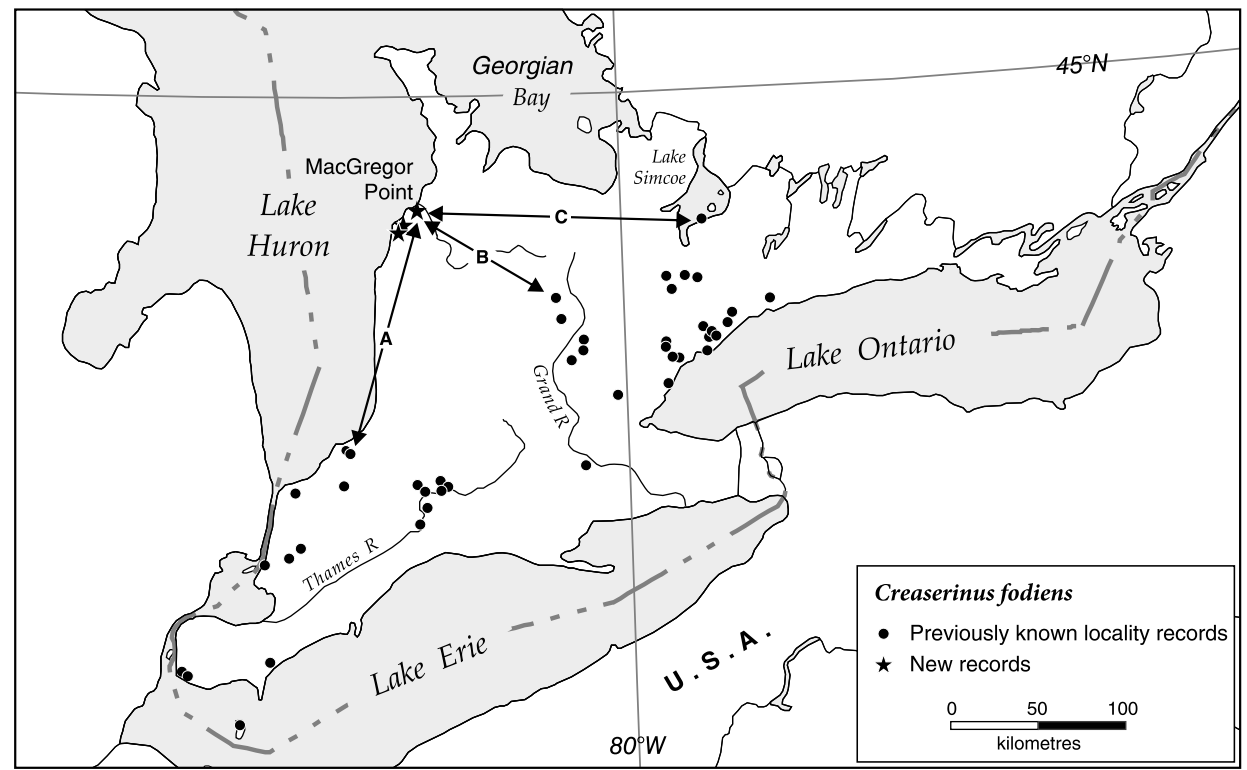

Fig. 2. The distances between the closest previously known Ontario distribution records for Creaserinus fodiens (Cottle, 1863) and the newly reported location at MacGregor Point.

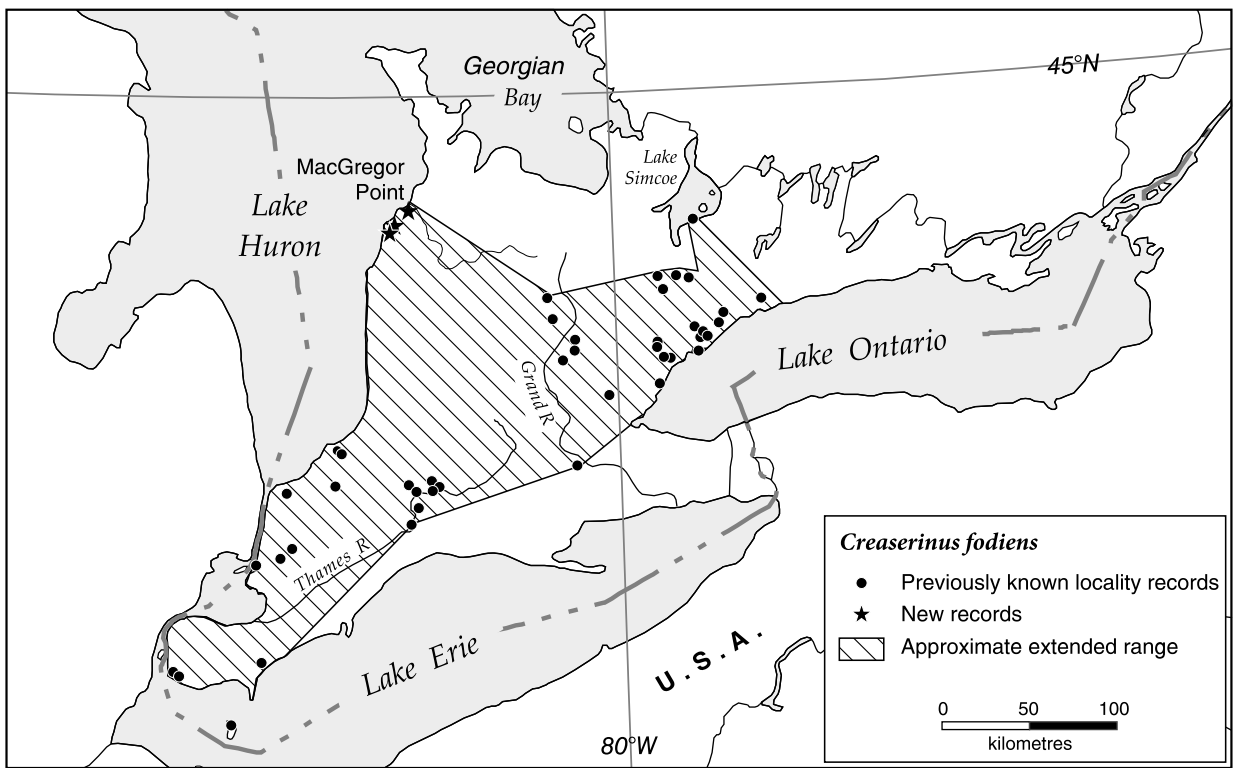

Fig. 3. The newly extended range of Creaserinus fodiens (Cottle, 1863) in Ontario, taking into account the new distribution records at and near MacGregor Point. 
The previous northernmost location reported for $C$. fodiens by Guiaşu et al. (1996a) was on the south shore of Lake Simcoe $\left(44^{\circ} \mathrm{N} 79^{\circ} \mathrm{W}\right)$, to the southeast of the newly reported locations. In 2006, Hamr discussed additional range extensions for this burrowing crayfish in Ontario. These range extensions included new locations on the southeastern shores of Georgian Bay, a northern expansion, and the northeast shore of Lake Scugog, an eastern expansion.

\section{CRAYFISH SPECIES ASSOCIATIONS}

The Creaserinus fodiens specimens found at the new Ontario locations reported in this study were collected by Taco den Haas and David Stanley during June and July 2006. During this field work, specimens of another burrowing crayfish, Faxonius immunis (Hagen, 1870), were also collected at some of the same locations as the $C$. fodiens. These specimens (of both species) were then brought to my attention, and I have subsequently examined the specimens and determined the species, sex, and male form (I or II) of each crayfish (Stanley, 2006). Two of these specimens (two form I males) were then stored in the crayfish collections of the Royal Ontario Museum, which are the largest collections of their kind in Ontario. The museum catalogue number for these specimens is ROMIZ L4456. Subsequently, in 2007, the new locations were included in an updated distribution map of $C$. fodiens in Ontario, which was prepared in collaboration with cartographers from the Cartography Office at the University of Toronto. Although these specimens were collected and identified several years ago, these distribution records were never analysed before in a peer-reviewed scientific study.

In various parts of its large North American range, $C$. fodiens was collected together with the following other crayfish species:

U.S.A.

Kentucky: Cambarus diogenes Girard, 1852, Cambarus sp. A, Faxonius immunis (Hagen, 1870), Faxonius palmeri palmeri (Faxon, 1884), Procambarus acutus (Girard, 1852), Procambarus clarkii (Girard, 1852), and Procambarus viaeviridis (Faxon, 1914) (cf. Taylor \& Schuster, 2004).

Ohio: Cambarus diogenes, Faxonius immunis, Faxonius rusticus (Girard, 1852), and Procambarus acutus (cf. Jezerinac \& Thoma, 1984); Cambarus diogenes (cf. Norrocky, 1991).

West Virginia: Cambarus bartonii cavatus Hay, 1902, Cambarus thomai Jezerinac, 1993, Faxonius virilis (Hagen, 1870), and Procambarus acutus (cf. Loughman \& Simon, 2011).

\section{CANADA}

Ontario: Faxonius immunis (cf. Hamr, 1998, 2006; present study); Cambarus robustus Girard, 1852 and Faxonius rusticus (cf. Guiaşu, 2007).

The fact that the semi-terrestrial, primary or secondary burrowing crayfish $C$. fodiens is sometimes found at the same locations as other crayfishes with similar habitat requirements, such as Cambarus diogenes, Cambarus thomai, Faxonius immunis, Procambarus acutus, and Procambarus clarkii, is not surprising. All of 
these species can be found in wetlands, swamps, floodplains, and drainage ditches (Taylor et al., 2015). However, as can be seen above, there are regional differences in species associations. For example, the primary or secondary burrowing species $C$. diogenes and $C$. fodiens were found at the same locations in Ohio, where they sometimes even shared burrows (Jezerinac \& Thoma, 1984; Norrocky, 1991), but were never recorded together at any Ontario locations (Guiaşu et al., 1996a; Hamr, 2006; Guiaşu, 2007). This may be due to the fact that the two species may have slightly different habitat requirements in Ontario, or may be in competition with each other in this province (Crocker \& Barr, 1968; Guiaşu et al., 1996a).

However, the occasional coexistence of primary and secondary burrowers, such as $C$. fodiens, with river and lake crayfishes with generally very different habitat requirements, such as $C$. robustus, $F$. rusticus and $F$. virilis, seems unusual and may require additional information and context. Clearly, crayfish species that live in streams and lakes are not normally found at the same locations as semi-terrestrial, burrowing crayfishes such as $C$. fodiens and $F$. immunis, which can be collected even relatively far away from permanent bodies of water (Guiaşu, 2002a; Guiaşu \& Guiaşu, 2003). It is generally fairly easy to predict which crayfish species are likely to be encountered at various locations by the type of habitat present there. For example, in Ontario, Cambarus bartonii bartonii (Fabricius, 1798) is usually found in rapids, waterfalls, and fast-flowing, cold streams with high oxygen content, in the central areas of the province, whereas $C$. robustus is primarily a species of the large rivers, and $C$. fodiens is located mainly in drainage ditches and wetlands in southern Ontario, where its presence is usually revealed by the mud chimneys built by individuals of this species above their burrows (Guiaşu et al., 1996b; Guiaşu, 2002b; Guiaşu \& Guiaşu, 2003).

I never found $F$. virilis and $C$. fodiens at the same locations during my many years of field work in Ontario, but, in one instance, I did encounter C. robustus, F. rusticus and C. fodiens in the same Ontario creek: the Little Rouge Creek, just north of Toronto. However, this was a rather unusual situation, and it appeared that some $C$. fodiens individuals may have fallen from a drainage ditch, which contained a population of these burrowing crayfish, into the waters of the creek below. The creek contained populations of two typical river crayfish species, $F$. rusticus and $C$. robustus, but the few $C$. fodiens individuals present there were only found in the vicinity of the adjacent drainage ditch, in the shallow waters near the muddy bank of the stream where the drainage ditch ended (Guiaşu, 2007). Although F. rusticus can occasionally survive in areas with wet mud and little surface water, this is not typical or optimal habitat for this species (Guiaşu, 2007). Also, while $C$. fodiens can be found occasionally in small streams, this semi-terrestrial burrowing crayfish is unable to maintain station in streams with moderate or fast currents and can therefore be swept downstream rather easily in 
such conditions (Bovbjerg, 1952; Bouchard, 1974; Williams et al., 1974; Maude \& Williams, 1983; Guiaşu, 2007). Therefore, due to their very different habitat requirements, $F$. rusticus and $C$. fodiens are unlikely to be found together, except in unusual circumstances, such as the ones described above.

\section{TAXONOMIC NOTES}

Recently, Crandall \& De Grave (2017) elevated the subgenus Creaserinus Hobbs, 1973 (previously a subgenus within the genus Fallicambarus Hobbs, 1969) to full generic status and assigned the crayfish formerly known as Fallicambarus fodiens to this new genus, thereby renaming this species Creaserinus fodiens. As a result, I am using this new species name in this study, even though the previous scientific name for this crayfish is still found in the Ontario museum records I examined as well as on the relevant IUCN ("International Union for Conservation of Nature", or, simply characterized, the "World Conservation Union") webpage.

Crandall \& De Grave (2017) also assigned the surface water crayfish species previously grouped in the genus Orconectes Cope, 1872 to the genus Faxonius Ortmann, 1905. All Faxonius species mentioned in this study used to be placed in the genus Orconectes prior to the publication of the study by Crandall \& De Grave (2017). However, the crayfish species belonging to the genera Cambarus Erichson, 1846 and Procambarus Ortmann, 1905 were not affected by the taxonomic changes recommended by Crandall \& De Grave (2017). Therefore, the Cambarus and Procambarus species discussed in this article retain their classical, wellestablished scientific names - at least for the time being.

\section{HISTORICAL DISTRIBUTION RECORDS IN ONTARIO}

In order to analyse the history of the scientific efforts for collecting crayfish related to Creaserinus fodiens in Ontario, I examined all available records in the relevant databases of the Royal Ontario Museum (ROM) in Toronto and the Canadian Museum of Nature (CMN) in Ottawa. These are by far the largest and most comprehensive scientific collections of crayfish available in Ontario, and therefore examining these collections should give access to most of the information about the distribution of this species in this Canadian province. Two ROM records and one CMN record had no collection year given, and, as a result, these records were excluded from the analysis below.

I will discuss the ROM records first, followed by the CMN records, and then I will analyse the combined data from the two museum collections.

ROM data.- The data from this museum show that $C$. fodiens specimens were collected during eight different decades in Ontario (fig. 4). The first record was 


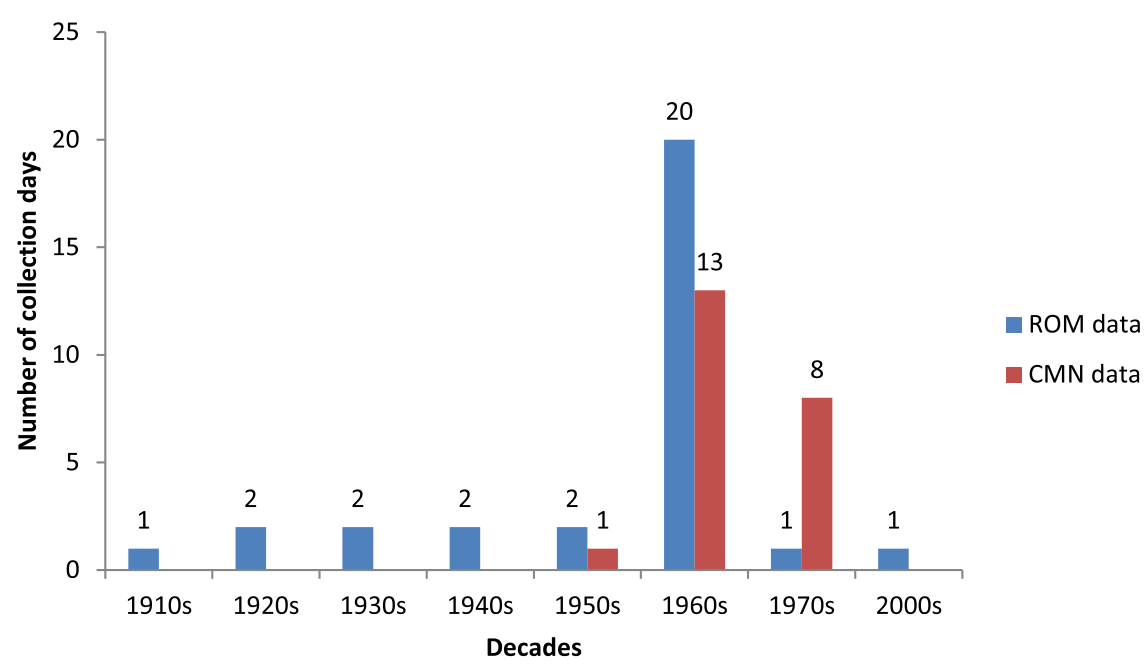

Fig. 4. Collection efforts related to Creaserinus fodiens (Cottle, 1863) crayfish in Ontario per decade, based on the information in the Royal Ontario Museum (Toronto) and the Canadian Museum of Nature (Ottawa) crayfish databases. The data from the two museum collections are presented separately, side by side, for comparison purposes.

from 1919 and the most recent from 2006. The most recent record is the one discussed in a previous section of this article. However, in these eight decades, C. fodiens crayfish were collected in only 16 different years, for a maximum total

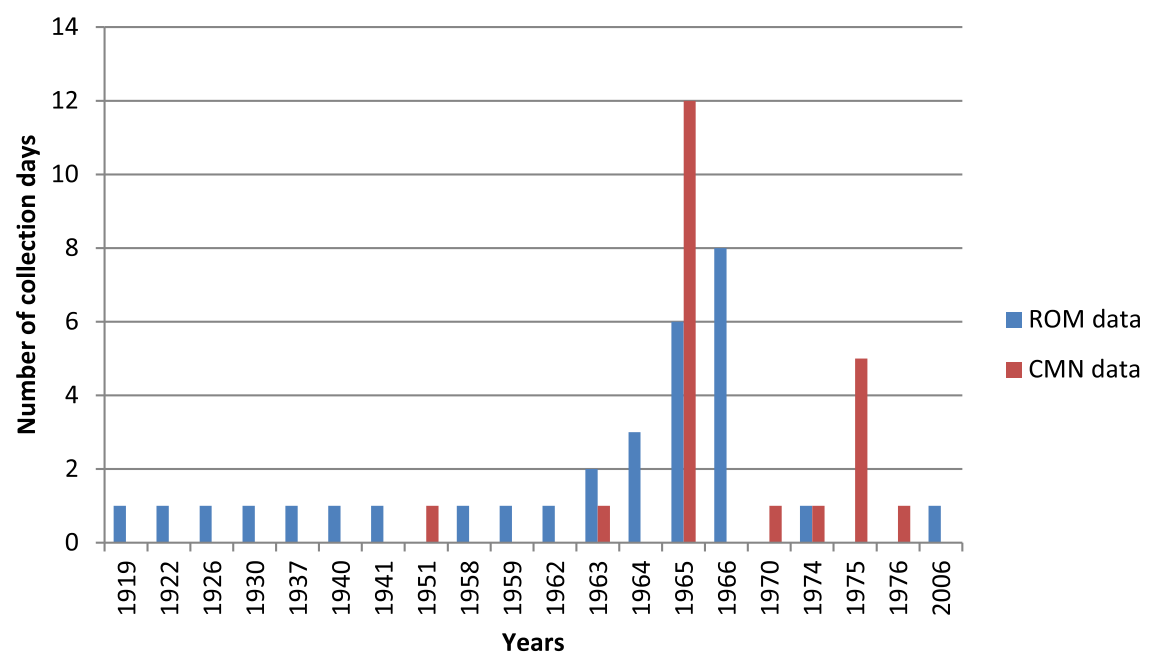

Fig. 5. Collection efforts related to Creaserinus fodiens (Cottle, 1863) crayfish in Ontario per year, based on the information in the Royal Ontario Museum (Toronto) and the Canadian Museum of Nature (Ottawa) crayfish databases. The data from the two museum collections are presented separately, side by side, for comparison purposes. 
number of just 31 total collection days (fig. 5). It should be noted that two of these collection days (one from 1965 and one from 1966) are not clearly specified. In both these cases, only the collection month and year are mentioned (July 1965 and April 1966, respectively), and, since there were other specific collection days mentioned for different $C$. fodiens ROM records for both July 1965 and April 1966, I could not be sure if the unspecified collection days were different from the ones which were clearly stated. However, because the records were different, I decided to treat the unspecified dates as different from the specified ones. If these unspecified collection days are not different, then the total number of collection days for this crayfish species revealed by the ROM records would drop to 29 . As mentioned, I chose the higher numbers ( 6 collection days for 1965 and 8 for 1966), but I acknowledge the possibility that the lower numbers (5 collection days in 1965 and 7 in 1966) could be the accurate ones. In any case, this minor discrepancy, which cannot be resolved based on the information available in the museum database, should not have a significant impact on the interpretation of the data overall.

In 12 of the 16 years when $C$. fodiens was collected, there was only one collection day per year, and there was only one decade (the 1960s) when there were more than 2 collection days per decade (figs. 4 and 5). In fact, most collection efforts for $C$. fodiens documented in the ROM database were made during just 4 years (1963, 1964, 1965 and 1966), and especially during the 1964-1966 period. The ROM database revealed that many of these more intensive collection efforts in the 1960s were made by David Barr. It seems clear that the noticeably higher number of collection days in the 1960s in search of this, and other, crayfish species in this province was related to the preparation and eventual publication of the book on Ontario crayfishes by Crocker \& Barr (1968), which, even after all these years, remains the most comprehensive work of its kind. The field work done for this book explains the spike in collection days from the 1960s (fig. 4).

Only 2 C. fodiens records were added to the ROM crayfish database in the 54 years since 1966. These two records were from 1974 and 2006, respectively. Therefore, there were no ROM records for this species at all from the 1980s and the 1990s, and no new records since 2006.

CMN data.- The CMN data reveal that $C$. fodiens crayfish were collected during only three decades (the 1950s, 1960s and 1970s) (fig. 4), and in these three decades crayfish of this species were collected in only 7 different years, for a total number of only 22 collection days (fig. 5). In 5 of the 7 years when $C$. fodiens was collected, there was only one collection day per year. The earliest record comes from 1951 and the most recent one from 1976 (fig. 5). Aside from the one collection day in 1951, all other collection efforts were undertaken in the 1960s and 1970s (13 and 8 collection days, respectively), and were mainly the result of the 
work of two researchers. All but one of the records from the 1960s were obtained by William Judd, and became part of his paper on the crayfish of the London, Ontario region (Judd, 1968), and all but one of the 1970s records were the result of collection efforts by Frederick Schueler. Furthermore, all the crayfish collected by William Judd came from a single county, i.e., Middlesex County, where the city of London is located, and therefore these collections were limited to a relatively small region in southern Ontario. No crayfish specimens of this species were added to the CMN collections since 1976 - a period of 44 years, almost twice the amount of time (25 years) elapsed between the oldest and newest $C$. fodiens $\mathrm{CMN}$ records.

Combined ROM and CMN data.- The ROM collection data for $C$. fodiens obviously cover a much longer period of time (87 years) than the CMN data for this crayfish ( 25 years). The first ROM record for this species was obtained more than three decades ( 32 years) before the first CMN one, and the most recent ROM record was added 30 years after the most recent CMN one (fig. 5). Only ROM records of $C$. fodiens were added during five of the eight decades when this species was collected. There was not a single decade during which CMN records were added without ROM records also being added for this crayfish, and the number of collection days was higher in the CMN database in comparison to the ROM database only in the 1970s (fig. 4).

Overall, in the 101 years that passed since the first $C$. fodiens museum specimen was recorded in Ontario, this species was collected for a maximum total of only 53 days (assuming the higher ROM numbers, as discussed above) in only 20 different

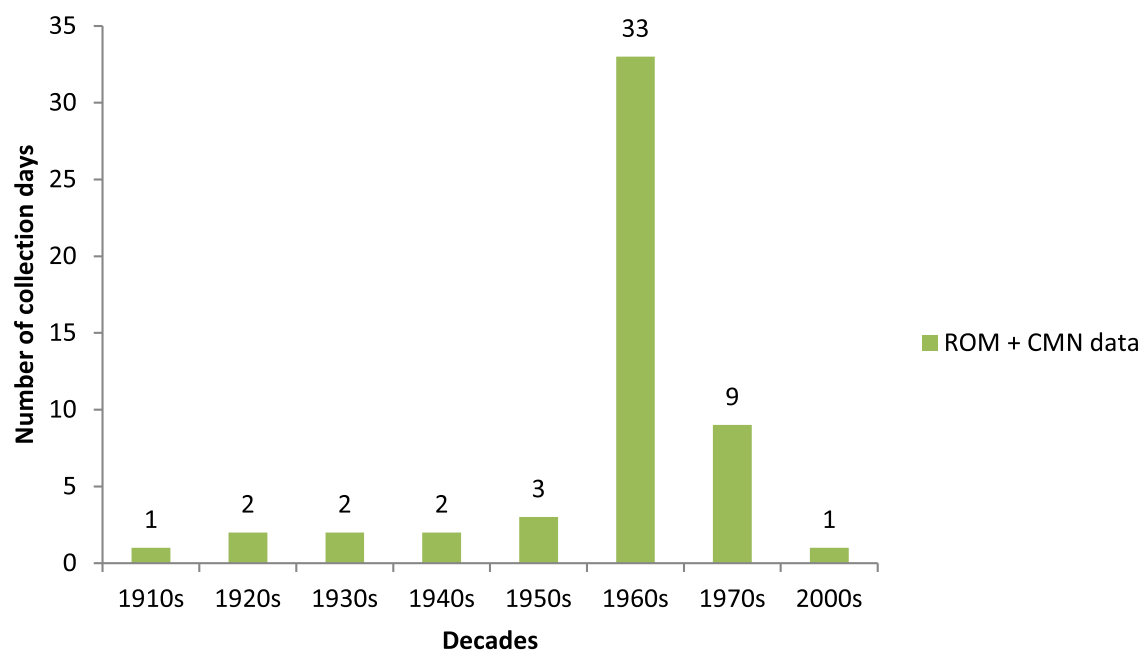

Fig. 6. Collection efforts related to Creaserinus fodiens (Cottle, 1863) crayfish in Ontario per decade, based on the combined information from the Royal Ontario Museum (Toronto) and the Canadian Museum of Nature (Ottawa) crayfish collections. 


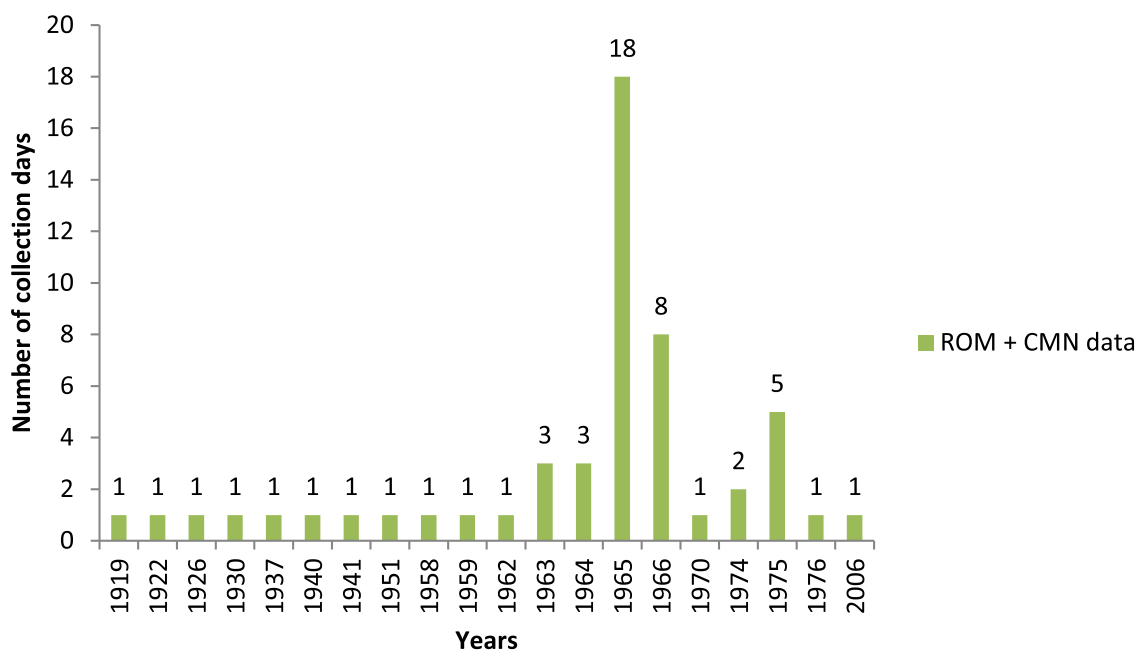

Fig. 7. Collection efforts related to Creaserinus fodiens (Cottle, 1863) crayfish in Ontario per year, based on the combined information from the Royal Ontario Museum (Toronto) and the Canadian Museum of Nature (Ottawa) crayfish collections.

years (figs. 6 and 7). Thus, in the more than a century since the first specimen of this species was collected, the total collection effort amounted to about seven and a half weeks. In 14 of the 20 years when $C$. fodiens was collected, there was only one collection day per year. The number of collection days per year only reached double digits during one year (1965). There was only one $C$. fodiens record added since 1976, and there were no new records at all since 2006 (fig. 7).

Other than the somewhat more sustained and systematic field work done in the mid-1960s (mainly in 1965 and 1966) for specific purposes, such as gathering data for a couple of studies (Crocker \& Barr, 1968; Judd, 1968), the C. fodiens collection efforts in Ontario can be characterized as sporadic, rare, and exceedingly incomplete. As a result, we have a relatively poor understanding of the changing distribution of this species in this province, and the same can be said about the other Ontario crayfishes. The oldest Ontario crayfish museum records are from the early $20^{\text {th }}$ century (Guiaşu, 2016), so we have almost no idea about the distribution of these species before that time, and an extremely incomplete picture of these distributions ever since (Guiaşu, 2009, 2016). C. fodiens, and some other crayfish species mentioned in this study, such as $C$. diogenes, $C$. robustus, and $F$. virilis, are considered native to Ontario, while the rusty crayfish (F. rusticus) is regarded as an invasive species in this province. Native species are supposed to have arrived in this province on their own - in other words, without human assistance at some point in the 10000 years or so since the end of the last Ice Age in this region, whereas non-native species arrived presumably with direct or indirect help from people. However, given the scarcity of historical data, also illustrated by this 
analysis, the reality is that we have very limited information about when and how different species reached particular regions. Thus, caution should be exercised when the geographic origins of species and their native or non-native status in various jurisdictions are analysed (Guiaşu, 2008, 2016; Guiaşu \& Tindale, 2018; Pereyra \& Guiaşu, 2020).

Furthermore, distribution maps for various species are usually based on cumulative records obtained over time, but species may sometimes no longer be present at some of the older locations. For example, some of the Toronto area locations which used to have $C$. fodiens colonies decades ago (Crocker \& Barr, 1968) no longer have suitable habitat for burrowing crayfish due to urbanization and related development for industrial and commercial purposes (Guiaşu et al., 1996a; Guiaşu, 2007). In order to make informed decisions about the conservation status of these crayfishes in Ontario, there is an obvious need to update the information about their distribution in this province.

\section{CONSERVATION NOTES}

Due to its presumed widespread distribution, which may cover an area greater than 2.5 million $\mathrm{km}^{2}$ (NatureServe, 2020), Creaserinus fodiens is not considered to be a species of special conservation concern overall.

Thus, on the IUCN Red List of Threatened Species, the current conservation status of this crayfish species is Least Concern (Crandall, 2010). This list was accessed on 11 November 2011, 7 August 2017 and 14 September 2020, and the conservation status for $C$. fodiens remained the same throughout this period. However, the last assessment of the conservation status of this species for the IUCN was made in 2010 (Crandall, 2010), and this is the assessment still shown on the relevant IUCN web page. Similarly, according to the American Fisheries Society (AFS) Endangered Species Committee, Subcommittee on Crayfishes, the conservation status category for $C$. fodiens is Currently Stable (CS), which refers to a species "whose distribution is widespread and stable and is not in need of immediate conservation management actions" (Taylor et al., 2007). In the same study, Taylor et al. also list the conservation ranks for crayfish species found in the U.S.A. and Canada, according to the criteria established by the Nature Conservancy/NatureServe and the Network of Natural Heritage Programs. This system gives conservation rankings for species throughout their entire presumed native ranges and uses G or Global scale ranks, ranging from G1 or Critically Imperiled to G5, which refers to species that are "demonstrably widespread, abundant, and secure." The rank given for C. fodiens under this system is G5 (Taylor et al., 2007; Simon, 2011). The Taylor et al. (2007) assessment was an 
update of a previous survey of the conservation of crayfishes from the U.S.A. and Canada conducted by Taylor et al. (1996). In that earlier study, Taylor et al. also listed the conservation status for $C$. fodiens as CS or Currently Stable, which clearly shows that, overall, this species has the best, or safest and most stable, conservation status available in North America, and this status has not changed in the period of time between these major surveys. The most recent Global Status for C. fodiens found on the NatureServe website, accessed in September 2020, was G5 or Secure, and, according to the information on this website, this status was last reviewed in February 2016 (NatureServe, 2020).

However, while these global, or overall North American - since C. fodiens is only found in North America, rankings would suggest that this crayfish species is safe from a conservation standpoint, a closer look at the status in various regions of this continent reveals possible reasons for concern.

The distribution of $C$. fodiens is currently estimated to include one Canadian province (Ontario), and perhaps as many as 22 U.S. states (Alabama, Arkansas, Florida, Georgia, Illinois, Indiana, Kentucky, Louisiana, Maryland, Michigan, Mississippi, Missouri, North Carolina, Ohio, Oklahoma, Pennsylvania, South Carolina, Tennessee, Texas, Virginia, West Virginia, and Wisconsin) (NatureServe, 2020). The Canadian Province of Ontario is included in other major reviews of the range of this species (Crocker \& Barr, 1968; Guiaşu, 2007; Taylor et al., 2007; Crandall, 2010). However, there are some controversies about the extent of the range of this species in the U.S.A. For example, on the IUCN website for $C$. fodiens, only 19 U.S. states are listed as part of the native range of this crayfish. The IUCN list includes the states listed above, except for North Carolina, Pennsylvania, and Wisconsin (Crandall, 2010). In their comprehensive survey of the crayfish species of the U.S.A. and Canada, Taylor et al. (2007) listed 20 U.S. states as part of the range of $C$. fodiens. These authors included all the states listed by NatureServe (2020), except for Pennsylvania and Wisconsin.

The presence of $C$. fodiens in Wisconsin remains uncertain (Guiaşu, 2007). In their analysis of the crayfish species of Wisconsin, Hobbs \& Jass (1988) stated that the presence of $C$. fodiens in Wisconsin was not confirmed, although the authors thought it was possible that this species may be found in the southern parts of that state. This assumption was supported by the fact that $C$. fodiens is found in northern Illinois, near the southern border of Wisconsin (Page, 1985; Hobbs \& Jass, 1988; Hobbs \& Robison, 1989; Taylor \& Anton, 1999), and, therefore, this crayfish may have crossed into Wisconsin as well.

The first record of $C$. fodiens from Pennsylvania was reported quite recently by Loughman et al. (2018). This would explain why Pennsylvania was not included among the U.S. states where this species was present in the earlier reports by Taylor et al. (2007) and Crandall (2010), and why this state appears as part of the 
range of $C$. fodiens in the more recent information available on the NatureServe (2020) website (although the reference section on this website does not include the 2018 study by Loughman et al.). Loughman et al. (2018) concluded that C. fodiens was native to Pennsylvania, although establishing the native or nonnative status of many species can often be a rather subjective exercise, which may determine whether species are protected or discriminated against (Guiaşu, 2016; Pereyra \& Guiaşu, 2020). Therefore, the decision by Loughman et al. (2018) to label $C$. fodiens as a native species should benefit this species in Pennsylvania, and ensure further study and possibly also a measure of protection for these local burrowing crayfish populations. Since the first report of the presence of $C$. fodiens in Pennsylvania is very recent, the extent of its distribution and abundance, and therefore its conservation status, in this state remain unknown (Loughman et al., 2018).

The exclusion of North Carolina from the geographic range of $C$. fodiens given on the IUCN Red List website (Crandall, 2010) is puzzling, since this species has been considered to be a part of the crayfish fauna of this state in previous studies (Taylor et al., 1996, 2007; Cooper, 2010).

According to the information available on NatureServe (2020), the subnational or state and provincial conservation status ranks for $C$. fodiens are:

S1 or Critically Imperiled in West Virginia.

S2 or Imperiled in Missouri and Oklahoma.

S3 or Vulnerable in Alabama, Georgia, Indiana, Virginia, and the Canadian Province of Ontario. S4 or Apparently Secure in Illinois, Kentucky, Maryland, Michigan, and Ohio.

S5 or Secure in Arkansas, Louisiana, North Carolina, and Tennessee.

SNR or Unranked (due to conservation status not being assessed) in Florida, Mississippi, Pennsylvania, South Carolina, and Texas.

SU or Unrankable (due to lack of information) in Wisconsin.

Thus, even though the national conservation status rank for $C$. fodiens in the U.S.A. is N5, or Secure, this crayfish species has a subnational or state status rank of conservation concern (S1, S2, or S3) in 7 U.S. states, or one third of the 21 U.S. states where the presence of this species has been confirmed. The situation is clearly most serious in West Virginia, where $C$. fodiens is considered Critically Imperiled and therefore has a conservation status rank of S1. Only four $C$. fodiens populations were reported from West Virginia (Loughman \& Welsh, 2010), which led Loughman et al. (2012) to label this species as "one of West Virginia's rarest crayfish."

Furthermore, in 5 additional U.S. states this crayfish was found in, the conservation rank was not yet assessed. The state of Pennsylvania is among these five states, because, as mentioned, the first report of $C$. fodiens from that state was recently published and a thorough survey of the distribution and abundance of this species in Pennsylvania is not available (Loughman et al., 2018). Since the presence of 
C. fodiens in Wisconsin has not yet been confirmed (Guiaşu, 2007), as previously discussed, no clear distribution information from this state is available, and, therefore, the state conservation status rank could not be assigned in this case. Overall, C. fodiens was assigned a Secure (S5) or Apparently Secure (S4) conservation status rank in only 9 (or $42.86 \%$ ) of the 21 U.S. states where its presence has been confirmed.

So, the national conservation status rank for this species in the U.S.A. can be somewhat misleading, since $C$. fodiens is only considered Secure or Apparently Secure from a conservation standpoint in less than half of the U.S. states where it is found. Furthermore, even in some states where $C$. fodiens has a Secure (or S5) conservation status rank, this crayfish species may be vulnerable in certain regions due to habitat degradation. For example, in Arkansas, $C$. fodiens was rare or absent in most rice-growing areas, and this decline in local burrowing crayfish populations was attributed to habitat modifications linked to the production of rice (Hobbs \& Robison, 1989).

In Canada, the national conservation status rank for $C$. fodiens is N3 or Vulnerable. This matches the Vulnerable (or S3) subnational or provincial conservation status rank assigned for this species in Ontario (NatureServe, 2020), which is not surprising, since Ontario is the only Canadian province where this burrowing, semi-terrestrial crayfish is found.

Following an examination of all available museum collection specimens as well as some new field work, Guiaşu et al. (1996) referred to $C$. fodiens as a vulnerable species in Ontario, where the probability of habitat destruction and related local population extinctions was found to be relatively high. The loss of wetlands is a major conservation concern for all species that depend on these habitats, including the burrowing crayfishes (Guiaşu, 2002a). Hamr $(1998,2006)$ suggested that $C$. fodiens should be regarded as a threatened species in Ontario, but, so far, as mentioned above, the conservation status rank for this province is still listed as vulnerable. The main threats to $C$. fodiens in Ontario remain habitat destruction and degradation, primarily associated with increasing urbanization and industrial and agricultural activities (Guiaşu et al., 1996; Guiaşu, 2002a, 2007). At this time, this species is not found in any of the "at risk" categories (Extirpated, Endangered, Threatened, and Special Concern) of the Canadian Wildlife Species at Risk list. In fact, there are no crayfish species on this list, as of October 2020. Since $C$. fodiens is also not present in the Not at Risk category on this list, it appears that this species was not yet assessed by COSEWIC (Committee on the Status of Endangered Wildlife in Canada) (COSEWIC, 2020).

In his review of the available information on $C$. fodiens for the IUCN Red List website, Crandall (2010) mentioned "competition from introduced crayfish species (Orconectes rusticus, Procambarus clarkii and Cambarus robustus)" as a threat to 
Fallicambarus (the genus to which this primary burrower had been assigned at that time) species, including $C$. fodiens, and cited one of my studies (Guiaşu, 2007) as the only reference in support of this assertion. However, this citation is somewhat misleading, since that is not the information I was presenting in that study. In that section of the Guiaşu (2007) article, I was referring to the conservation and ecology of $C$. fodiens in Ontario, and I noted that in one very unusual case a few $C$. fodiens individuals were found in a small stream together with $C$. robustus and $F$. rusticus (referred to as $O$. rusticus on the IUCN website). However, semi-terrestrial burrowing crayfish, such as $C$. fodiens, are almost never encountered at the same locations as stream and lake species such as $C$. robustus and F. rusticus (cf. Guiaşu \& Guiaşu, 2003). I have collected and studied various crayfish species in Ontario for many years (since 1991), and I only encountered $C$. fodiens together with these river and lake species at one location, as discussed in a previous section of this study.

Furthermore, Cambarus robustus is not an introduced species in Ontario, and Procambarus clarkii is not present in Ontario waterways at this time (I only found one P. clarkii specimen, in an urban Ontario stream, nearly 30 years ago, and it is very likely that specimen had been recently released, possibly from a teaching lab). There is no evidence of any established populations of $P$. clarkii in Ontario and I am not aware of any other sightings of this species in the wild in this province. It is also unclear if $P$. clarkii, which tends to prefer warmer conditions and is most commonly found in southeastern areas of the U.S.A. (Walls, 2009), can survive Canadian winters (Guiaşu, 2007). Thus, since P. clarkii is not currently found in Ontario, this species obviously cannot have any effect on the C. fodiens populations in this province at the present time. It may also be worth noting that the conservation status rank of $C$. fodiens is listed as S4 or Apparently Secure in Kentucky and S5 or Secure in Louisiana, where this species coexists with $P$. clarkii, which is also known as the Louisiana red swamp crayfish. These two species were found at some of the same locations in Kentucky (Taylor \& Schuster, 2004), as mentioned in an earlier section of this study, and they are also both found in several other states, such as Louisiana, Arkansas, and Tennessee (Taylor et al., 2007), where $C$. fodiens is secure from a conservation standpoint. In Louisiana, for example, the ranges of $C$. fodiens and $P$. clarkii occupy most of the state and overlap broadly, and both are very common there. In fact, $C$. fodiens was described as "the most commonly collected burrowing crayfish" in Louisiana (Walls, 2009). Thus, the coexistence of these two species does not necessarily have to be detrimental to $C$. fodiens. Due to their very different habitat requirements, it is also extremely unlikely that $C$. robustus or $F$. rusticus would interact with $C$. fodiens in any significant way, if at all, and therefore, these lake and river crayfish species are not expected to pose a threat to $C$. fodiens. 
Although, as previously mentioned, $C$. fodiens is normally found in wetlands and drainage ditches, Taylor et al. (2010) also discovered this species in two caves in Missouri. The cave specimens of $C$. fodiens had some morphological features, such as longer antennae, which were significantly different from those of conspecifics from more typical, surface habitats. Therefore, cave populations of this species may have unique features and require special attention from a conservation standpoint.

Based on an analysis of genetic data, Ainscough et al. (2013) found that C. fodiens is a species complex, which likely contains multiple species with distinct distributions. These authors suggested the need for additional research particularly on the northern populations of $C$. fodiens found in Canada and the northeastern regions of the U.S.A. in order to get a better understanding of the evolutionary relationships within this species complex. These findings have potential conservation implications as well. For example, if $C$. fodiens is indeed a species complex containing several species, then it is possible that at least some of these species may be vulnerable from a conservation standpoint. For example, if the northern $C$. fodiens populations of Canada, which are currently considered vulnerable, or other imperiled $C$. fodiens populations in certain regions of the U.S.A., are found to belong to distinct species, then the Global conservation status of such species would have to be changed as well, from the G5 or Secure conservation status rank currently assigned to the entire $C$. fodiens lineage, to a conservation status rank which would better reflect the special conservation concerns.

\section{ACKNOWLEDGEMENTS}

Taco den Haas and David Stanley collected crayfish at the new locations, brought these specimens to my attention and asked me to identify these crayfish. Gary Varsava of the Ontario Power Generation Inc. (OPG) gave written permission to report the presence of some burrowing crayfish colonies from a site owned by the OPG. Byron Moldofsky and Mariange Beaudry of the Cartography Office, within the Department of Geography, at the University of Toronto, updated the distribution maps and provided the requested biogeographic measurements. Maureen Zubowski, of the Royal Ontario Museum (ROM), generously made the large ROM crayfish database available to me, which was very helpful for updating the distribution maps and the discussion of the museum records for this crayfish species in Ontario. Silviu Guiaşu offered assistance with the preparation of the graphs. 


\section{REFERENCES}

Ainscough, B. J., J. W. Breinholt, H. W. Robison \& K. A. Crandall, 2013. Molecular phylogenetics of the burrowing crayfish genus Fallicambarus (Decapoda: Cambaridae). Zoologica Scripta, 42: 306-316. DOI:10.1111/zsc12006.

BouchaRD, R. W., 1974. Geography and ecology of crayfishes of the Cumberland Plateau and Cumberland Mountains, Kentucky, Virginia, Tennessee, Georgia and Alabama. Part II. The genera Fallicambarus and Cambarus. Freshwater Crayfish, 2: 585-605.

BovBJERG, R. V., 1952. Comparative ecology and physiology of the crayfish Orconectes propinquus and Cambarus fodiens. Physiological Zoology, 25: 34-56.

CoOper, J. E., 2010. Annotated checklist of the crayfishes of North Carolina, and correlations of distributions with hydrologic units and physiographic provinces. Journal of the North Carolina Academy of Science, 126: 69-76.

COSEWIC, 2020. Canadian wildlife species at risk. October 2020. (Committee on the Status of Endangered Wildlife in Canada, Ottawa, ON). https://www.canada.ca/en/environment-climatechange/services/species-risk-public-registry/cosewic-list-species-assessed.html [Downloaded on 24 November 2020.]

Crandall, K. A., 2010. Fallicambarus fodiens. The IUCN Red List of Threatened Species 2010: e.T153747A4539897. http://dx.doi.org/10.2305/IUCN.UK.2010-3.RLTS. T153747A4539897.en [Downloaded on 10 November 2011, 7 August 2017 and 14 September 2020.]

Crandall, K. A. \& S. De Grave, 2017. An updated classification of the freshwater crayfishes (Decapoda: Astacidea) of the world, with a complete species list. Journal of Crustacean Biology, 37: 615-653.

Crocker, D. W. \& D. W. BARR, 1968. Handbook of the crayfishes of Ontario: 1-158. (University of Toronto Press, Toronto, ON).

Guisşu, R. C., 2002a. Tunnel syndrome. Rotunda - The Magazine of the Royal Ontario Museum, 35: 22-27.

GuiAșu, R. C., 2002b. Cambarus. In: D. M. Holdich (ed.), Biology of freshwater crayfish: 609634. (Blackwell Science, Oxford).

GuiAşu, R. C., 2007. Conservation and diversity of the crayfishes of the genus Fallicambarus Hobbs, 1969 (Decapoda, Cambaridae), with an emphasis on the status of Fallicambarus fodiens (Cottle, 1863) in Canada. Crustaceana, 80: 207-223.

GuiAşU, R. C., 2008. Specious claims? The Royal Ontario Museum Magazine, 40: 26-33.

Guiaşu, R. C., 2009. Conservation, status, and diversity of the crayfishes of the genus Cambarus Erichson, 1846 (Decapoda, Cambaridae). Crustaceana, 82: 721-742. DOI:10.1163/ $156854009 X 407722$.

GUIAşU, R. C., 2016. Non-native species and their role in the environment: the need for a broader perspective: i-xii, 1-316. (Brill, Leiden and Boston, MA).

Guiaşu, R. C., D. W. BARR \& D. W. Dunham, 1996a. Distribution and status of crayfishes of the genera Cambarus and Fallicambarus (Decapoda, Cambaridae) in Ontario, Canada. Journal of Crustacean Biology, 16: 373-383.

Guiaşu, R. C., D. W. Dunham \& D. W. BARR, 1996b. Interspecific agonistic contests between male Cambarus bartonii bartonii (Fabricius, 1798) and Cambarus robustus Girard, 1852 (Decapoda, Cambaridae) crayfish and the possible competition between the two species in Ontario. Freshwater Crayfish, 11: 364-377.

Guiaşu, R. C. \& S. Guiaşu, 2003. Entropy in ecology and ethology: 1-330. (Nova Science Publishers, New York, NY).

Guiaşu, R. C. \& C. Tindale, 2018. Logical fallacies and invasion biology. Biology \& Philosophy, 33: 34. DOI:10.1007/s10539-018-9644-0. 
HAMR, P., 1998. Conservation status of Canadian freshwater crayfishes: 1-87. (World Wildlife Fund $\&$ The Canadian Nature Federation, Toronto, ON).

HAMr, P., 2006. The distribution and conservation status of burrowing crayfishes Fallicambarus fodiens and Cambarus diogenes in Canada. Freshwater Crayfish, 15: 271-282.

НоввS III, H. H. \& J. P. JASS, 1988. The crayfishes and shrimp of Wisconsin: 1-177. (Milwaukee Public Museum, Milwaukee, WI).

Hobbs JR., H. H. \& H. W. Robison, 1989. On the crayfish genus Fallicambarus (Decapoda, Cambaridae) in Arkansas, with notes of the fodiens complex and descriptions of two new species. Proceedings of the Biological Society of Washington, 102: 651-697.

JEZERINAC, R. F. \& R. F. ThOMA, 1984. An illustrated key to the Ohio Cambarus and Fallicambarus (Decapoda: Cambaridae) with comments and a new subspecies record. Ohio Journal of Science, 84: 120-125.

JUDD, W. W., 1968. Crayfish in the vicinity of London, Ontario. National Museum of Canada Natural History Papers, 41: 1-9.

Loughman, Z. J. \& T. P. Simon, 2011. Zoogeography, taxonomy, and conservation of West Virginia's Ohio River floodplain crayfishes (Decapoda, Cambaridae). ZooKeys, 74: 1-78.

Loughman, Z. J. \& S. A. Welsh, 2010. Distribution and conservation standing of West Virginia crayfishes. Southeastern Naturalist, 9 (Special Issue 3): 63-78.

Loughman, Z. J., S. A. Welsh \& T. P. Simon, 2012. Occupancy rates of primary burrowing crayfish in natural and disturbed large river bottomlands. Journal of Crustacean Biology, 32: 557-564.

Loughman, Z. J., P. Woods \& D. A. Lieb, 2018. First record of Creaserinus fodiens (digger crayfish) from Pennsylvania. Northeastern Naturalist, 25: 15-18.

MAUdE, S. H. \& D. D. Williams, 1983. Behaviour of crayfish in water currents: hydrodynamics of eight species with reference to their distribution patterns in southern Ontario. Canadian Journal of Fisheries and Aquatic Sciences, 40: 68-77.

NATURESERVE EXPLORER, 2020. https://explorer.natureserve.org/Taxon/ELEMENT_GLOBAL_ 2.106957/Creaserinus_fodiens [Accessed on 30 September 2020.]

NORROCKY, M. J., 1991. Observations on the ecology, reproduction and growth of the burrowing crayfish Fallicambarus (Creaserinus) fodiens (Decapoda, Cambaridae) in north-central Ohio. American Midland Naturalist, 125: 75-86.

Page, L. M., 1985. The crayfishes and shrimps (Decapoda) of Illinois. Illinois Natural History Survey Bulletin, 33: 335-448.

Pereyra, P. J. \& R. C. GuiAşU, 2020. Debate about the importance and meaning of native range in invasion biology: reply to Courchamp et al. Conservation Biology, 34: 1044-1046.

Simon, T. P., 2011. Conservation status of North American freshwater crayfish (Decapoda: Cambaridae) from the southern United States. Proceedings of the Indiana Academy of Science, 120: 71-95.

STANLEY, D., 2006. Phase II: assessment of the crayfish species and population investigation in project and representative offsite areas at the Western Waste Management Facility: 1-15. (Technical Report 06-1112-026. Ontario Power Generation, Toronto, ON).

TAYlor, C. A. \& T. G. Anton, 1999. Distributional and ecological notes on some of Illinois' burrowing crayfishes. Transactions of the Illinois State Academy of Science, 92: 137-145.

TAYlor, C. A. \& G. A. Schuster, 2004. The crayfishes of Kentucky. Illinois Natural History Survey Special Publication, 28: i-viii, 1-219. (Illinois Natural History Survey, Champaign, IL).

Taylor, C. A., G. A. Schuster, J. E. Cooper, R. J. DiStefano, A. G. Eversole, P. Hamr, H. H. Hobbs III, H. W. Robison, C. E. Skelton \& R. F. Thoma, 2007. A reassessment of the conservation status of crayfishes of the United States and Canada after 10+ years of increased awareness. Fisheries, 32: 372-386. 
TAylor, C. A., G. A. Schuster \& D. B. Wylie, 2015. Field guide to crayfishes of the Midwest. Illinois Natural History Survey Manual, 15: 1-145. (Illinois Natural History Survey, Prairie Research Institute, Champaign, Illinois).

TAYlor, C. A., M. L. WArren, JR., J. F. FitzPatrick, JR., H. H. Hobbs, III, R. F. JezerinaC, W. L. Pflieger \& H. W. Robison, 1996. Conservation status of crayfishes of the United States and Canada. Fisheries, 21: 25-38.

TAYLOR, M. S., B. B. Blechle \& B. S. PoBst, 2010. Morphological divergence between cave and surface populations of the digger crayfish, Fallicambarus fodiens (Cottle, 1863) (Decapoda, Cambaridae). Crustaceana, 83: 1303-1313. DOI:10.1163/001121610X535555.

Walls, J. G., 2009. Crawfishes of Louisiana: 1-240. (Louisiana State University Press, Baton Rouge, LA).

Williams, D. D., N. E. Williams \& H. B. N. Hynes, 1974. Observations on the life history and burrow construction of the crayfish Cambarus fodiens (Cottle) in a temporary stream in southern Ontario. Canadian Journal of Zoology, 52: 365-370.

First received 27 November 2020.

Final version accepted 19 December 2020. 